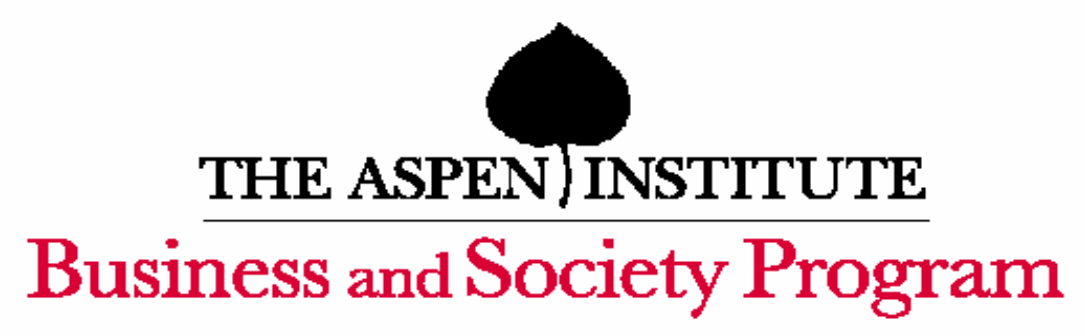

\title{
INSTITUTIONS AND THE VICIOUS CIRCLE OF DISTRUST IN THE RUSSIAN HOUSEHOLD DEPOSIT MARKET, 1992-1999
}

\author{
By: Andrew Spicer and William Pyle
}

William Davidson Institute Working Paper Number 588

June 2003 


\title{
INSTITUTIONS AND THE VICIOUS CIRCLE OF DISTRUST IN THE RUSSIAN \\ HOUSEHOLD DEPOSIT MARKET, 1992-1999
}

\author{
ANDREW SPICER \\ The A. Gary Anderson Graduate School of Management \\ Anderson Hall \\ University of California, Riverside \\ Riverside, CA 92521 \\ andrew.spicer@ucr.edu \\ WILLIAM PYLE \\ Middlebury College \\ Economics Department \\ Middlebury, VT 05753
}

\section{DRAFT}

February 2003

\footnotetext{
An earlier version of this paper was published in Advances in Strategic Management, 2002, 19: 371-396. We would like to thank the University of California's Academic Senate, the A. Gary Anderson Graduate School of Business and Middlebury College for funding to support this research. We also thank Wendy Bailey, Bruce Kogut, Livia Markoczy and Mikhail Matovnikov for helping us develop the ideas present in this draft.
} 


\title{
INSTITUTIONS AND THE VICIOUS CIRCLE OF DISTRUST IN THE RUSSIAN HOUSEHOLD DEPOSIT MARKET, 1992-1999
}

\author{
ABSTRACT \\ In our analysis of the Russian household deposit market during the 1990s, we \\ show how the initial conditions of market emergence contributed to a vicious circle in \\ which private commercial banks progressively lost the trust of potential depositors. The \\ roots of this destructive dynamic lay in the initial conditions of market emergence. Initial \\ experiences of fraud and financial loss led Russian households to distrust that commercial \\ banks would honor their contractual obligations. As distrust grew and became more \\ ingrained, the competitive conditions in the deposit market changed in a way that further \\ increased the gains to opportunism and decreased the returns to trust production. In a \\ self-reinforcing process, fraud begat more fraud.
}


Market reform in the transitional economies of Eastern Europe and the former Soviet Union requires a twist on the question usually examined by organizational theorists. The contemporary theory of the firm assumes the presence of markets and inquires as to the origins and purposes of organization. Economic reform in former communist countries focuses our attention on a different question: given the existence of organizations, how do markets develop?

Gerschenkron's (1962) work on late development provides one way to analyze the emergence of new markets in post-communist societies. He argues that industrialization processes in less developed countries differ considerably from more advanced countries in the productive and organizational structures of industry that emerge from economic change. Markets, in this case, represent one of multiple institutional forms by which development may take place. For instance, in describing the banking system in Tsarist Russia, he writes:

The scarcity of capital in Russia was such that no banking system could conceivably succeed in attracting sufficient funds to finance a large-scale industrialization; the standards of honesty in business were so disastrously low, the general distrust of the public so great, that no bank could have hoped to attract even such small funds as were available, and no bank could have successfully engaged in long-term credit policies in an economy where fraudulent bankruptcy has been almost elevated to the rank of general business practice. (Gerschenkron, 1962: 19)

The failure of banks to act in a trustworthy manner, and the subsequent distrust of these banks on the part of investors, led to the failure of commercial banks to attract "even such small funds as were available." Without trust, markets could not develop. Although he was writing about an earlier time, Gerschenkron (1962) could 
have been describing the Russian banking in the 1990s. Initial theorists of postcommunist economic reform argued that markets could develop rapidly if the entrepreneurial incentives of private activity could be unleashed through the liberalization of prices and the privatization of state owned property (Boycko et. al., 1995; Sachs, 1993). However, the Russian household deposit market demonstrates the challenges in recreating markets in new institutional settings. As we will show throughout the paper, both the standards of honesty in business during the 1990s, as well as the general distrust of the public, was so great that no commercial bank was able to attract a significant portion of household savings. Despite the presence of hundreds of commercial banks that offered deposit services, Russians hid billions of dollars worth of their savings at home.

The failure of Russia's deposit markets raises a number of important questions about the role of trust in the development of new markets. Why did competitive forces lead to the devolution, rather than evolution, of a new market? Why were individual banks unable or unwilling to invest in mechanisms of trust production to survive in a declining market? Moreover, what was the role of the state in market decline? Gerschenkron (1962: 48), for instance, posits that in the financial markets of Tsarist Russia "the activities of the government effectively substituted for the lacking prerequisite of minimum acceptable standards of commercial honesty." What role should government play in the capital markets of post-communist Russia?

We build upon Zucker's (1986) distinction between "process-based" and "institutional-base" trust to examine both the causes and persistence of distrust toward commercial banks in the Russian deposit market. "Process-based" trust, Zucker explains, 
is tied to the behavior of a specific actor. An individual or organization may either build a reputation for trustworthiness through repeated exchange or undertake some action, such as branding, that credibly signals to others one's reliability. "Institutional-based trust," on the other hand, is a product of formalized social structures. Trust in economic exchange is based not on the characteristics or history of a particular actor, but instead on confidence in third-party organizations, political structures or social norms to dictate common standards of good conduct.

A defining feature of institutional trust is its impersonality. If interpersonal trust is based on the relationship between individuals, institutional trust is based on the expectation that collective rules will be applied in a predictable and fair manner independently of the personal connections of the individuals involved. Zucker credits the emergence of mechanisms of institutional trust with the development of mass markets in the United between the mid-1800s to the early 1900s. She argues that mechanisms of process-based trust proved unequal to the task of facilitating exchange across geographical distances and ethnic groups. Instead, institutional trust enabled exchange between strangers because the members to an exchange trusted an intermediary structure, whether it be professional credentialing, financial intermediation or government regulation, to safeguard market exchange.

Coleman's (1990) distinction between systems and relationship of trust helps to clarify the nested layers of analysis inherent in the study of institutional trust. Relations of trust refer to the mutual relationship between two actors, a trustor and a trustee. Systems of trust refer to those elements of the environment that influence the decision of an individual actor to place or break trust. Like Zucker, Coleman argues that social 
systems influence the ability of individuals to engage in trusting relationships. Economic actors may rely on the judgment of an intermediary, the power of a third-party regulator or the strength of a social norm when deciding whether to engage in a particular trust relation.

Transaction cost economics usually focuses on relations of trust in examining the costs and structure of contractual exchange. Each transaction is assumed to be separable and independent of arrangements of other transactions. In contrast, institutional trust views the production of trust as a collective endeavor: "if trust is violated on one transaction, trust will be disrupted in other transactions; transactions, at least those based on trust, are generally not separable but are bundled and they interact.” (Zucker, 1986:66) Trust carries with it the definition of specific contexts, what Zucker calls constitutive expectations, which provide the basis for subsequent transactions.

We identify the process by which the experience of a single transaction becomes generalized to similar transactions as a "reputational externality." On one hand, markets and expectations may co-evolve in a virtuous circle of trust production. If customers experience successful outcomes in their early transactions in a new market, then trust in subsequent transactions grows. However, a reputational externality may work in a negative direction as well. If customers experience negative outcomes in their early participation in a new market, then trust in subsequent transactions decreases. Markets and expectations may co-evolve in a vicious circle of mutual decline.

We argue that it was the mutual interaction of firm strategies and depositor expectations that led to the collapse of the Russian deposit market. The Russian population was initially willing to experiment in the deposit market, demonstrating an 
inclination to trust commercial banks with their savings. However, these initial attitudes changed over time. Fraudulent bankruptcies and pyramid schemes led to the emergence of distrust toward all financial intermediaries in post-communist Russia. The Russian population did not evaluate where to place their savings by assessing which commercial bank was trustworthy, but, more fundamentally, tried to assess whether any commercial bank was trustworthy.

Although this period of "wild capitalism" during the early 1990s may be characterized as having provided a necessary, albeit harsh, lesson for inexperienced investors about the need for diligence in market exchange, we see the effects as less benign and more permanent. As distrust grew and became more ingrained, the competitive conditions in the deposit market changed in a way that further increased the gains to opportunism and decreased the returns to trust production. In a self-reinforcing

process, fraud begat more fraud. Russian deposit market entered into a vicious circle of distrust in the 1990s that has been extremely difficult to reverse.

After briefly outlining the origins of the Russian household deposit market, we then examine the macro-level data that demonstrate its fate from 1992 to 1999 . We then explore the micro-institutional processes that underpinned the decline of the Russian market. We demonstrate that in Russia the short-term rewards to abusing trust have outweighed the long-term rewards to producing it.

\section{The Rise and Fall of the Russian Household Deposit Market}

An understanding of why households grew to distrust private savings organizations must begin with a review of the rapid transformation of Russia's banking 
sector just prior to the dissolution of the Soviet Union's centrally planned economy. Until the late 1980s, the Soviet government prohibited all private financial organizations and Sberbank (the state-owned savings bank) was the only institution allowed to accept the savings of households. Sberbank operated thousands of branches and service counters across the country, offering both savings and demand deposits. After 1957 and the discontinuation of forced government bond purchases, households quickly began to increase their savings in Sberbank as state-run media advertised the confidentiality and liquidity of its deposits. Many branches offered payroll deduction plans, served as local collection points for telephone bills and distributed pension checks (Garvy, 1977). By the 1960s, Sberbank had developed into a trusted institution and an important presence in the daily lives of Soviet citizens.

The rest of the state banking system had no direct contact with households. It was a highly centralized organization, fully subordinated to the political leadership and its production plan for real goods and services. But in the late 1980s, it was restructured in a manner that would greatly influence the banking environment confronting households in the early 1990s. In 1988, as a part of Mikhail Gorbachev's perestroika reform program, the state bank was divided into two tiers, a central bank and several specialized banks charged with serving the financial needs of state-owned firms in specific sectors of the economy. Legislation passed in 1990 formally advanced the dissolution of the old state monobank by calling for the break-up of the specialized banks and their transformation into joint-stock, commercial banks. But changes were already occurring more rapidly at the sub-national level. As early as 1989, the government of the Russian republic required banks on its territory to transform themselves into commercial banks (Abarbanell and 
Meyendorff, 1997). In the next couple of years, as the Soviet state weakened and the government of the Russian republic grew in power and influence, hundreds of branches of the specialized banks split off from their parent organizations to form autonomous banking units, licensed by the Central Bank of Russia (CBR).

The perestroika reforms of the late 1980s also included measures allowing for the development of a private, cooperative sector. To support its development, the ban on non-state banks was lifted, allowing new credit institutions to be established. The Soviet central bank set few formal requirements for their registration, gave them the right to access cheap financial resources from the state and established only modest capital requirements. Despite having set up little in the way of regulatory structures to oversee them, hundreds of new banks with no institutional roots in the old system were allowed to register in just a couple of years.

Because of these developments, in January 1992, just after the Soviet Union's break-up and concurrent to Russia's rapid economic liberalization, there were 1360 banks registered in Russia. The policies of the late Soviet period had left Russia the most heavily banked country in the former socialist bloc. Cheap credit from the CBR and a continuation of the lax policies on capital standards contributed to additional growth. By January 1995, the number of banking institutions in Russia climbed to 2527 (Bulletin of Banking Statistics).

In holding over $99.7 \%$ of all household deposits, Russia's Sberbank had a de facto monopoly in the household savings market when the institutional basis for private savings was laid down in January 1992. Almost immediately thereafter, many of the recently created commercial banks, as well as non-bank financial institutions, entered this 
new market. None of these new entrants had a reputation, either for good or bad, among potential depositors. Even though some had been hived off from the state bank and could thus trace their origins back to the Soviet system, they had not developed reputations as savings institutions. In other words, any sort of repeated interaction that could support "process-based trust" between households and the new institutions was largely absent. Sberbank was the only established player. And though it began the reform era with several distinct advantages, like its competitors, it had no real experience in honoring liabilities within a market setting.

Effective public regulatory bodies were also missing in the new household savings market. These would have to be created from scratch. The CBR's licensing procedures, for instance, were extremely lax; and capital requirements were negligible, allowing basically any group with the right political connections to open a bank. Furthermore, the CBR's capacity to monitor bank behavior, including the riskiness of loan portfolios, was virtually non-existent in the early 1990s. Although formal rules had been put in place (e.g., minimum reserve requirements and capital adequacy standards), most analysts believed that their effectiveness was limited, in part due to an insufficient number of well-trained personnel.

On the other side of the market, Russian households were quite naïve about these new financial organizations. They had had very little experience with making investment decisions under socialism and little or no exposure to assessing financial risk. A population reared under centralized planning, after all, had limited exposure to bankruptcies and other stories of financial failure. 
Ironically, perhaps because of households' ignorance, the market for their deposits grew quickly in the months following January 1992. According to official data, the net inflow of their ruble savings into bank deposits expanded quickly in the years following market liberalization. Figure 1 shows how households nearly doubled their net bankbased savings rate from the first half of 1992 to the first half of $1994 .{ }^{2}$ This initial surge in the flow of savings into the banking system could be attributed exclusively to the increased rate of saving in new commercial banks. Indeed, by June 1994, after having been in operation for effectively two-and-a-half years, the private banking sector had accumulated $49.3 \%$ of the stock of all bank-based household savings. These developments were particularly noteworthy when considering the significant competitive advantages possessed by Sberbank. Not only did it have an extensive pre-existing branch network and an explicit government guarantee to stand behind its deposits, Sberbank also was able to offer many services not available from its competitors, such as transfers for utility fees, taxes and pensions. 
Figure 1: Percentage of After Tax Personal Income Held in Bank Deposits, 1992-

1997

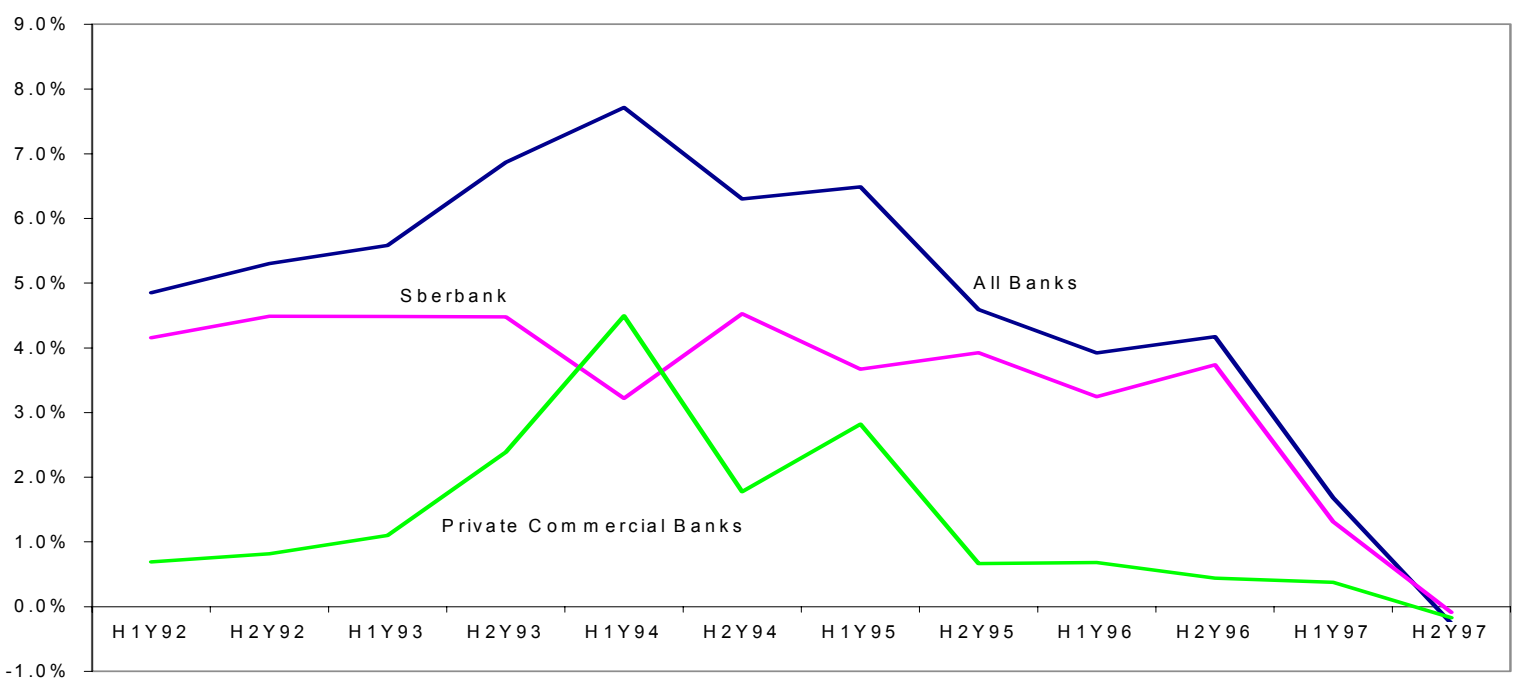

Note: The horizontal axis portrays time in half-year increments (e.g,. H2Y93 refers to the second half of 1993). The percentages were calculated by taking the difference in the stock of deposits between January 1 st and July $1^{\text {st }}$ of the given time periods and dividing this by after tax household income earned over the same period. The one exception is the $\mathrm{H} 297$ data; the percentages there were calculated using changes in deposit data from July $1^{\text {st }}$ to December $1^{\text {st }}$; this is due to a redefinition of the series (noted in the text below) on January $1^{\text {st }} 1998$.

Source: Bulletin of Banking Statistics, Central Bank of Russia (various issues). 


\section{Table 1: Interest Rates on Time Deposits at Leading Banks in Retail Market, March 1995}

\begin{tabular}{|l|c|c|c|c|}
\hline Name of Bank & 1-month & 3-months & 6-months & 9-months \\
\hline Sberbank & $7 \%$ & $22 \%$ & $50 \%$ & $83 \%$ \\
\hline Inkombank & -- & $30 \%$ & $60 \%$ & $90 \%$ \\
\hline Promstroibank Rossii & $7 \%$ & $24 \%$ & -- & -- \\
\hline Mezhregionbank & $9 \%$ & $35 \%$ & -- & -- \\
\hline Unikombank & $9 \%$ & $27 \%$ & $54 \%$ & $82 \%$ \\
\hline Vozrozhdenie & -- & $36 \%$ & $87 \%$ & $153 \%$ \\
\hline Tver'universalbank & $7.9 \%$ & $26 \%$ & -- & -- \\
\hline Natsional'nyi kredit & $10 \%$ & $35.5 \%$ & $86 \%$ & $108 \%$ \\
\hline Stolichnyi Bank & $8.7 \%$ & $33 \%$ & $65 \%$ & $98 \%$ \\
\hline
\end{tabular}

Note: Time series data on bank deposit rates are not available.

Source: Bazhenova et. Al. (1995). 
By the summer of 1994, it appeared as though a robust market for household deposits had developed. By and large, the new market pitted the higher deposit rates (see Table 1) and heavier advertising of the new private banks against the services, locational convenience and apparent institutional stability of Sberbank. The private savings market seemed to be thriving in spite of the relatively short period in which the stock of impersonal trust had time to grow.

As they were increasing their savings in private banks, households also rapidly expanded their investments in new non-bank financial institutions. The Russian government estimated that up to 2,000 unlicensed companies operated on the financial markets between 1992-1994, attracting the equivalent of $\$ 5-7$ billion from 80 million Russian investors (Federal Commission, 1996). An "unlicensed" company is: (a) a financial company that undertakes activities outside its legal scope, or (b) a company that operates on the market without any type of government license. A financial company engages in activity outside its legal scope if it undertakes activities that are not included in the rules that define the organizational form of which it is a member. For instance, a company that has a license as a "financial broker" might offer a contractual promise that is equivalent to a bank deposit even though it has no license to act as a bank. A financial company that operates without any type of legal license simply opens up operations in the absence of any sort of license to engage in financial transactions.

Figure 2 shows the results of one survey that identified the number unlicensed financial companies in Moscow by month from 1993-1994 that promised the equivalent of 'bank deposit' contracts with clients (Federal Commission, 1996a). 
Figure 2: Unlicensed Financial Companies in Moscow , 1993-1994

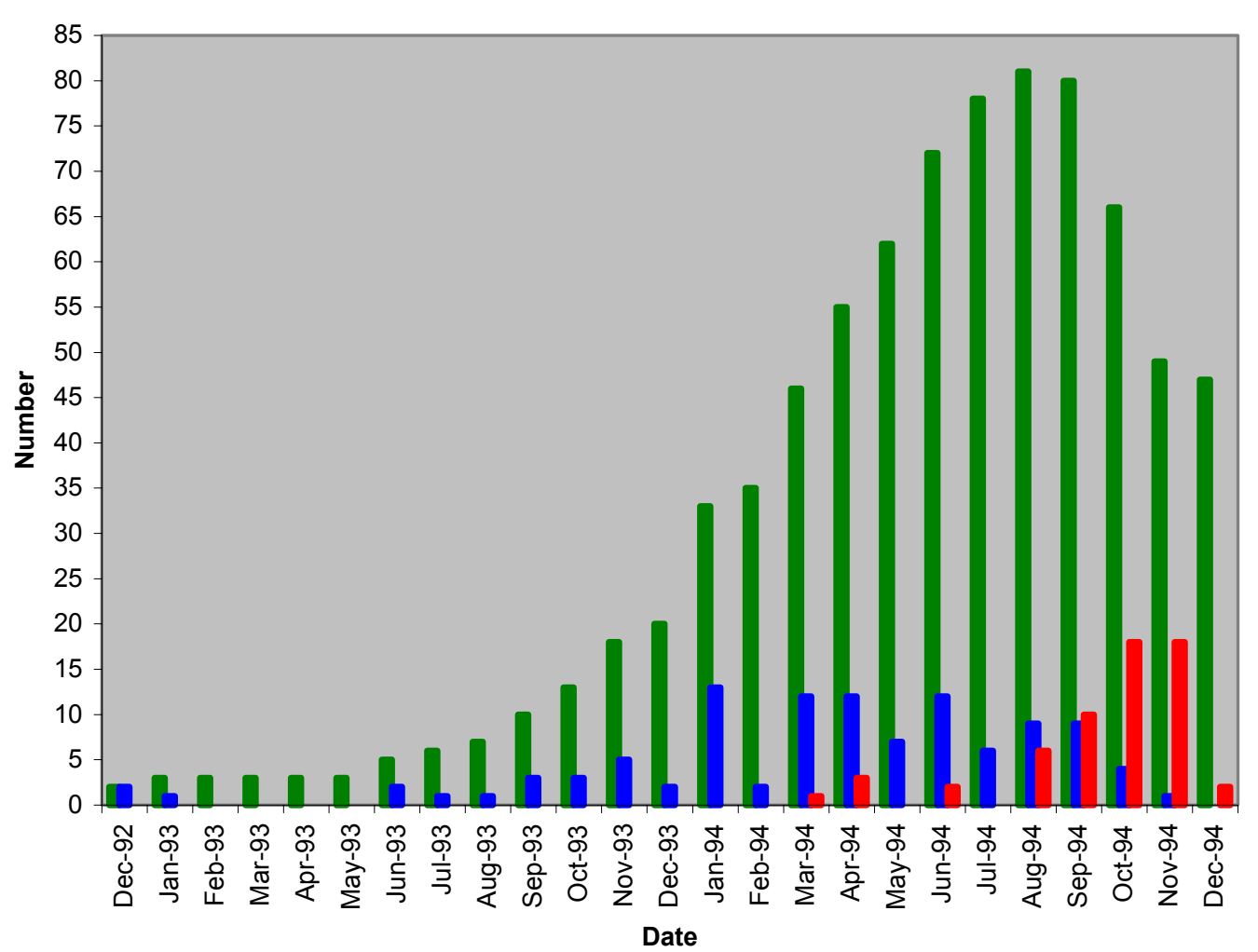

Number of unlicensed companies actively operating with clients (culmulative)

Number of new unlicensed companies (market entry by month)

Number of unlicensed companies that closed doors to customers (market closure by month)

According to the legal requirements of the Russian financial markets, only organizations with banking licenses to create deposit accounts for personal savings had the legal right to engage in this type of behavior. Yet, as the study demonstrates, over 100 companies in Moscow engaged in promissory contracts that were the equivalent of bank deposit contracts even in the absence of a formal license to do so. This research identified the day that the financial company started and ended offering "banking" services to clients, as no sort of legal category could be defined to identify the birth and death of this type of organizational form. The average operating life-span of these companies in Moscow was 
seven months. The report states that by August 1995 only seven unlicensed financial companies still existed on Russia's financial company.

Although some were legitimate intermediaries, many were no more than pyramid schemes. MMM, the largest and most notorious of these, sold shares that promised to yield absurdly high returns in relatively short periods of time. Indeed, the initial wave of investors did make out well, since the company was able to pay them off with the investments of those that arrived later. The scheme could not last long, however. The company crashed in July 1994, its share price dropping from sixty-four dollars to fifty cents in the course of a single day. Investors lost between one and two billion dollars in personal savings.

Another company, Tibet, was not a bank in any legal sense, yet it was able to engage in a number of activities that mimicked retail banking. In nationally broadcast commercials in March 1993, it offered 30\% monthly deposit rates, a nominal annual return of over $2000 \%$. Over 600,000 investors from cities throughout Russia placed the equivalent of $\$ 3$ million into the company. When Tibet went bankrupt after eleven months of operation, a mob of depositors stormed its headquarters to appropriate office equipment and other fixed assets to compensate for their lost savings. ${ }^{3}$

The inability of many of these un-licensed institutions to live up to their outrageous promises clearly had a negative impact on the ability of commercial banks to attract deposits. In fact, the collapse of MMM in July 1994 coincided precisely with the abrupt reversal of savings trends in private commercial banks. At this time, there had been no significant failures of licensed commercial banks. ${ }^{4}$ But households, perhaps understandably, did not draw clear distinctions between private banks and un-licensed 
pyramid schemes. Both, after all, were competing for the same household deposits. Looking back at Figure 1, we see that the second half of 1994 was the first period in the market era during which there was a decline in the bank-based savings rate. Having saved in net terms over $4 \%$ of their income in private commercial banks in the first half of the year, households restricted the increase in deposits to under $2 \%$ of their income in the second half. In Sberbank, however, the rate of net inflows actually increased during the same period in which it was decreasing in the private sector. Sberbank, that is, seemed to be the immediate beneficiary of the scandals in the private sector. But the failures of some private financial institutions seemed to have had a negative impact on all. In the three years following the MMM collapse, the flow of household savings into all commercial banks fell from roughly $8 \%$ to under $2 \%$ of after tax personal income. And though Sberbank did not entirely escape this trend, overwhelmingly the decline was due to an increased aversion to private banks.

Although the reversal of the 1992-1994 trend was precipitated by the collapse of non-bank financial institutions, it may have been exacerbated by the shaky performance of licensed banks a year later. For banks, 1994 had been a profitable year (Warner, 1998). But the insolvency of several large players on the overnight interbank market in Moscow produced a severe system-wide liquidity crisis in August 1995. The CBR provided temporary re-financing to some, but several major private banks were allowed to go bankrupt. These events, no doubt, only re-enforced a growing lack of confidence in banks. In 1996, private banks attracted less than $1 \%$ of households' after-tax personal income. In the second half of 1997, households actually reduced their stock of savings in private banks. 
Table 2 provides further evidence for early optimism preceding a growing display of distrust toward private banks. A respected Russian polling agency asked a random sampling of citizens in at least four different Russian cities the following question: "If you have (or had) money savings, in what way would you prefer to keep them in the present situation?" Respondents were allowed to choose one or more answers from the following options: Sberbank; private commercial banks; government bonds; company shares; cash rubles; hard currency; in goods (e.g., jewels, antiques, paintings, etc.); or "other." ${ }^{5}$ The responses follow the same patterns as the aggregate data on actual household savings behavior. Through 1994, the public displayed a growing willingness to entrust their savings to private banks. In fact, between June 1993 and February 1994, the increase in the stated desire to save in private banks outpaced all of the other savings options. 
Table 2: Survey Data on Intended Investment Decisions: "If you have (or had)

money savings, in what way would you prefer to keep them in the present

\section{situation?"}

\begin{tabular}{|c|c|c|c|c|c|c|c|c|}
\hline & $\begin{array}{c}\text { Respon- } \\
\text { dents }\end{array}$ & Sberbank & $\begin{array}{c}\text { Private } \\
\text { Banks }\end{array}$ & $\begin{array}{c}\text { Gov't } \\
\text { Bonds }\end{array}$ & Stocks & Cash & $\begin{array}{c}\text { Foreign } \\
\text { Currency }\end{array}$ & Goods \\
\hline $\mathbf{6 / 9 3}$ & 1628 & $42.4 \%$ & $14.1 \%$ & $4.9 \%$ & $16.8 \%$ & $14.8 \%$ & $36.7 \%$ & $26.9 \%$ \\
\hline $\mathbf{1 0} / \mathbf{9 3}$ & 1392 & $36.7 \%$ & $19.1 \%$ & $4.5 \%$ & $16.3 \%$ & $13.7 \%$ & $33.9 \%$ & $31.7 \%$ \\
\hline $\mathbf{2} / 94$ & 1628 & $35.3 \%$ & $20.7 \%$ & $3.3 \%$ & $11.7 \%$ & $12.0 \%$ & $42.9 \%$ & $29.7 \%$ \\
\hline $\mathbf{1 / 9 5}$ & 2363 & $35.2 \%$ & $14.7 \%$ & $3.1 \%$ & $7.0 \%$ & $13.3 \%$ & $47.6 \%$ & $17.6 \%$ \\
\hline $\mathbf{3 / 9 5}$ & 1584 & $37.5 \%$ & $9.9 \%$ & $1.2 \%$ & $6.2 \%$ & $7.5 \%$ & $56.2 \%$ & $20.0 \%$ \\
\hline $\mathbf{4 / 9 5}$ & 2030 & $37.0 \%$ & $8.9 \%$ & $3.0 \%$ & $3.1 \%$ & $11.8 \%$ & $46.5 \%$ & $15.4 \%$ \\
\hline $\mathbf{3 / 9 6}$ & 2001 & $46.5 \%$ & $7.7 \%$ & $3.0 \%$ & $2.7 \%$ & $21.9 \%$ & $45.1 \%$ & $19.6 \%$ \\
\hline $\mathbf{3 / 9 7}$ & 1933 & $39.4 \%$ & $3.2 \%$ & $4.1 \%$ & $3.8 \%$ & $19.1 \%$ & $56.2 \%$ & $15.3 \%$ \\
\hline $\mathbf{6} / \mathbf{9 8}$ & 1902 & $31.2 \%$ & $2.1 \%$ & $0.6 \%$ & $3.5 \%$ & $26.0 \%$ & $61.1 \%$ & $17.1 \%$ \\
\hline $\mathbf{9 / 9 8}$ & 1991 & $29.8 \%$ & $2.0 \%$ & $0.6 \%$ & $3.3 \%$ & $24.9 \%$ & $58.4 \%$ & $16.4 \%$ \\
\hline $\mathbf{9} / \mathbf{9 9}$ & 2002 & $29.9 \%$ & $1.7 \%$ & $1.4 \%$ & $4.3 \%$ & $18.8 \%$ & $63.8 \%$ & $15.3 \%$ \\
\hline
\end{tabular}

Note: Respondents were able to respond in multiple categories. Respondents who did not answer the question directly were excluded from this reporting of the results. The dates reflect the time when the surveys were conducted, not necessarily the publication date of the journal.

Source: Compiled from Monitoring of Public Opinion, various issues, 1992-2000.

But after 1994, the trend reversed. From over $20 \%$ of the population in February 1994, the percentage of those expressing a willingness to save in private banks dropped to just over $2 \%$ in June 1998 . Only the bonds on which the Russian government would default later that summer were held in lower esteem. The increased aversion to private banks corresponded to an increase in the stated desire to save in foreign currency at home and relatively consistent responses to the desirability of saving in Sberbank.

Since official data on household savings before January 1, 1998 did not include foreign currency deposits, direct comparisons before and after that date are problematic. ${ }^{6}$ Nevertheless, we see in Figure 3 that since 1998 private commercial banks have continued to have trouble in attracting new inflows of deposits. The figure shows that, 
even though one might expect that households' capacity to save had increased because of the robust economic growth in Russia in 1999, and even though foreign currency deposits were now included in the deposit data, in net terms only about one percent of new income was deposited into private banks. ${ }^{7}$ The questionnaire data from this period confirm the extent of the distrust. Only $1.7 \%$ of those polled expressed a willingness to deposit monies in private banks.

\section{Figure 3: Percentage of After Tax Personal Income Held in Bank Deposits, 1998-1999 (Includes Foreign Currency Deposits)}

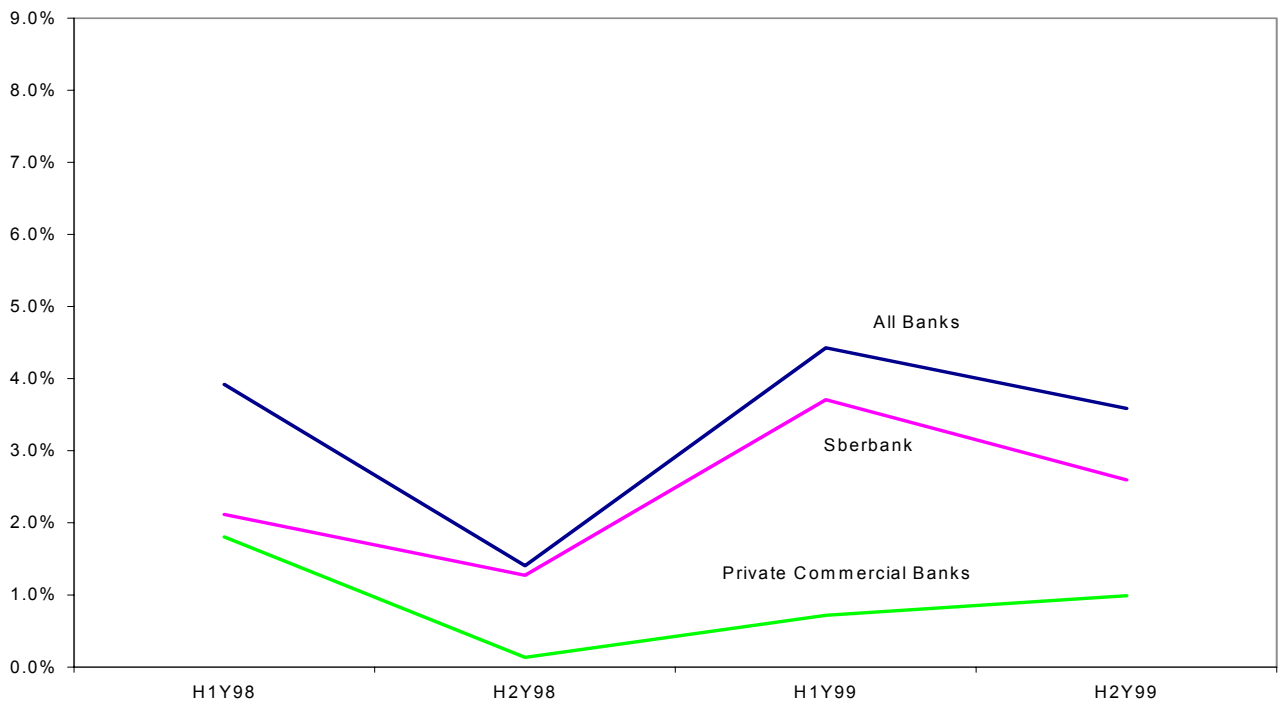

Source: Bulletin of Banking Statistics, Central Bank of Russia (various issues).

In no small part, the perpetuation of banks' image problem was brought about by the macroeconomic crisis of 1998. In August, the Russian government devalued the ruble and defaulted on its bond obligations. Because of their unbalanced exposure to hard currency liabilities and ruble-denominated assets, including government securities, a number of banks were driven into insolvency. Many of the largest were unable to meet 
their obligations to depositors, reinforcing strongly-held beliefs that commercial banks were not to be trusted.

\section{Firm Strategy and Institutional Distrust}

In this section, we re-orient our focus from a macro-level discussion of market trends and depositor attitudes to the micro-institutional factors that underpinned them. Specifically, we examine why individual firms either would not or could not develop "process-based" mechanisms of trust to overcome the broader lack of confidence in the market. We argue that the conditions under which the market initially developed reduced any single bank's ability to benefit from, and thus willingness to engage in, trustproducing behavior. The population of depositors, in turn, learned to become more skeptical of private banks. Subsequent entrants into the deposit market failed to reverse this learning process. Instead, distrust bred a continuation of untrustworthy behavior in a self-reinforcing process of market decline.

Russian households' lack of experience in interacting with a private financial sector left them poorly prepared to cope with the new market in two ways. For one, their appreciation for financial risks, generally, was minimal. For another, they had no experience in discriminating among specific options in a competitive financial market. The distinction between a legitimate commercial bank and a fly-by-night pyramid scheme was not meaningful. With the exception of Sberbank, all financial institutions effectively "looked" the same to households. 
Given the unformed nature of their beliefs about the financial sector, households' initial interactions with financial institutions would likely do much to shape their perception of the industry as a whole. That is, we might have expected there to be significant reputational externalities associated with the behaviors of individual firms. The creation of institutional understandings of what "banks" were and how they were supposed to behave involved a process of collective learning on the part of inexperienced investors. During the initial phase of market formation, one financial institution's good behavior (e.g., honoring deposit obligations in the promised manner) would positively influence the broader perception of the entire financial sector; bad behavior, conversely, would reflect negatively on all. Thus we saw that when pyramid schemes collapsed, the reputation of financial organizations, collectively, suffered.

The presence of these externalities most likely discouraged behaviors that would have produced process-based trust. The logic here is straightforward. When transaction costs are non-trivial and externalities are present, self-interested actors engage in too much of the behavior generating negative externalities and not enough of the behavior producing positive externalities. For private banks in Russia's nascent deposit market, the existence of reputational externalities weakened the incentives to behave well. The costs, after all, of pursuing a risky investment strategy that might lead to a failure to honor deposit contracts would not be fully internalized. Rather, they would be spread across the industry as a whole in the form of a damaged reputation. Likewise, the benefits of pursuing strategies that would increase the potential of meeting promised obligations would accrue to the collective. 
The massive, un-regulated entry of both licensed and un-licensed financial institutions into the household savings markets likely exacerbated the effects of reputational externalities. If this new market had had just a single bank, then its actions would have affected only its own reputation. But with hundreds of banks in the market for a limited stock of savings, the costs of opportunism and the benefits of trust production, from the perspective of a single firm, were minimal.

The unstable political and economic situation in Russia during these years exacerbated these disincentives for building trust. Hyper-inflation and political struggles between the executive and legislative branches left financial institutions uncertain about the types of opportunities that would be available in the future, thus decreasing their effective time horizons and diminishing the expected returns from any type of long-term investment, including trust production. The prospects for developing long-term relationships with households were not great in the highly volatile environment that characterized the first years after market liberalization. It should thus not be surprising that firms might choose behaviors at odds with building the basis for long-term interaction. Firm-level actions aimed at slowly and incrementally building the trust of households were unlikely to be fully rewarded.

But what of strategies that might have a more immediate impact? Could a bank that was serious about developing a long-term presence in the retail market for deposits credibly and quickly signal its intention to potential clients? Could trust be won without an extended relationship? The mere claim to be a trustworthy bank would not, by itself, be meaningful since it would be a relatively costless signal to send. The better firms must find alternative means to distinguish themselves. It has been suggested that 
advertising expenditures could in certain contexts serve this function (Nelson, 1974). In markets for "experience goods," clients of high quality providers should be more loyal and, consequently, more valuable to attract. ${ }^{8}$ Higher quality providers should thus be willing to incur greater up-front costs than other firms to attract new clients. Heavy expenditures on advertising (even advertising that is not particularly informative) could signal this willingness. A correlation between product quality and advertising expenditure might thus be expected in markets for experience goods.

The advertising expenditures of Russian banks and the credibility of their promises to depositors, however, do not exhibit this relationship. Avdasheva and Yakovlev (2000) provide evidence for a negative correlation between Russian banks' advertising expenditures and their market longevity in 1994. The greater the amount of advertising that a bank carried out, the more likely it was to disappear from the market. ${ }^{9}$ Indeed, in the third quarter of 1994, over a third of all advertising costs was incurred by banks that were no longer in operation a year later. Depositors thus learned to discount advertising as a signal of credibility. In fact, Avdasheva and Yakovlev provide survey evidence showing that households attached little weight to advertising when choosing where to make deposits. Savers reported giving greater attention to interest rates, location and the advice of friends. Advertising was reported to be the least important factor.

The banks that engaged in heavy advertising and then failed to honor their liabilities produced a negative externality. In addition to the reputational externality noted above, their actions de-valued a potential signaling mechanism that could have served, at least in part, as a mechanism for firms to produce process-based trust. In her 
discussion of trust production, Zucker (1986:65) observes that signals "cannot be solely symbolic - over time receivers will discount the signal unless it remains correlated with the underlying quality or characteristic it represents." In Russia, investors learned to distrust not only commercial banks but also potential market signals that could have enabled them to distinguish between trustworthy and untrustworthy competitors.

One interpretation of the initial period of institutional learning in the Russian deposit market was that it represented a harsh, but necessary, lesson for inexperienced investors about the need for diligence in market exchange. Indeed, one Russian banker noted that "The best lesson for the country as a whole seems to be the MMM fiasco ... The scandal actually taught the Russian people the lessons of capitalism, perhaps for the first time." (Yuri Lvov, advertisement for Bank St. Petersburg, EuroMoney, September 1994, 137, cited in Johnson, 2000: 112). Avdasheva and Yakovlev (2000:180) are similarly upbeat about the impact of the initial market experience. They present evidence of a positive correlation between a bank's advertising expenditures in 1995 and its longevity over the subsequent three-year period, arguing that the initial discrediting of advertising as a signal of quality laid the groundwork for its subsequent resuscitation:

Since the second half of 1995 the valuation of advertising by clients of private banks can be expressed as follows: 'I know that most people do not trust advertising campaigns and advertising itself can hardly attract a large amount of money. If any private bank invests money in advertising, this type of investment cannot bring a quick return. This means that the bank is going to stay in the market for a long period.'

In other words, since it had previously proven to be un-correlated with short-term profitability, advertising would now only make sense for firms that planned to be in the market for a long time. 
Unfortunately, Avdasheva and Yakovlev's data end in early 1998 so they are unable to assess the impact of the financial crisis that hit in August. This significantly distorts their conclusions. As we will see, the outcomes for depositors following the August 1998 crash only reinforced the general distrust of commercial banks. Far from providing a valuable learning experience or reviving a potential signaling mechanism, the initial growth of depositor distrust contributed to some of the very behaviors that led to widespread bank failures in the aftermath of the 1998 crisis.

\section{Deposit Banks and the August 1998 Financial Crisis}

In the mid-1990s, a number of new banks entered the deposit market to try to chip away at Sberbank's still dominant position. In January 1998, the stock of deposits in private banks amounted to approximately $25 \%$ of a 160 billion ruble market; six private banks held over one billion rubles each (see Table 3). The largest of these was SBSAgro. It had grown rapidly after 1994 when, as the Stolichny Bank of Savings (SBS), it had only sixty thousand private account holders. By 1996, SBS had five hundred thousand private depositors in sixty-seven branches (SBS Annual Report, 1996). That year, it also won a tender to rehabilitate Agroprombank, the former state agricultural bank that had recently gone bankrupt. The combined organization, SBS-Agro, controlled over 1300 branches and offices around the country. 
Table 3: Top Banks in Deposit Market, Pre-August 1998 Crash

\begin{tabular}{|l|c|c|c|}
\hline $\begin{array}{l}\text { Banks with over 1 } \\
\text { billion rubles of } \\
\text { deposits (Jan. 1998) }\end{array}$ & $\begin{array}{l}\text { Total Deposits } \\
\text { (Millions of } \\
\text { Rubles) }\end{array}$ & $\begin{array}{l}\text { Advertising } \\
\text { (Rank Order - } \\
\text { July 1998) }\end{array}$ & $\begin{array}{l}\text { Reliability } \\
\text { Rating (Jan. } \\
\text { 1998) }\end{array}$ \\
\hline Sberbank & $123,869.3$ & 5 & $\begin{array}{c}\text { A3 } \\
\text { (top rating) }\end{array}$ \\
\hline SBS-Agro* & $6,701.2$ & 2 & A1 \\
\hline Inkombank & $5,572.8$ & 4 & A2 \\
\hline Most-Bank & $2,174.4$ & 13 & A1 \\
\hline Menatap & $1,305.1$ & 6 & A1 \\
\hline $\begin{array}{l}\text { Promstroibank } \\
\text { Rossiya }\end{array}$ & $1,203.8$ & 30 & A2 \\
\hline Rossiiskii Kredit & $1,125.6$ & 1 & \\
\hline $\begin{array}{l}\text { Total Deposits in } \\
\text { Commercial Banks }\end{array}$ & $40,097.2$ & & \\
\hline $\begin{array}{l}\text { Total Deposit in Top } \\
\text { Six Commercial Bank }\end{array}$ & $18,082.9$ & & \\
\hline
\end{tabular}

* We combine the deposits of Stolicniy Bank (SBS) and Agroprombanka in this total.

Sources: Advertising is based on expenditures in July 1998, based on Gallup-International Figures (1998). Rating data is from Rating Information Center, www.rating.ru. Deposit data is from Interfax Rating Company.

SBS-Agro and the other leading private deposit banks received among the highest ratings given by the Rating Information Center (RIC) -- a Moscow-based financial information provider whose banking data had, at one point, been considered to be more reliable than the CBR's. ${ }^{10}$ RIC's monthly ratings placed banks on a "reliability" continuum from extreme reliability (A3) to satisfactory stability (B1), with banks judged to be below the B1 standard not appearing in the rankings at all. The largest six commercial banks, in terms of household deposits, all received " $A$ " grades for reliability at the end of 1997. 
Despite their apparent health, the biggest players on the commercial deposit market proved to be disproportionately vulnerable to the effects of the 1998 financial crisis. Table 4 compares the fate of the top six deposit banks with the other commercial banks that received an "A" rating from RIC at the end of $1997 .{ }^{11}$ By December 1998, all six of the top commercial deposit banks had fallen off RIC's rating list; these banks, that is, had either ceased to operate or did not merit even a "B" rating. On the other hand, of the sixteen other commercial banks that had received an "A" rating in the end of 1997, nine received a "B" rating or above. ${ }^{12}$ This comparison shows the August 1998 financial crisis did not lead to the collapse of all the largest commercial banks in Russia. Some of Russia's largest banks were able to survive with their reputations in tact. In contrast, all six of the leading deposit banks were unable to survive.

Table 4: Comparison of Rating Changes, Pre-Crash and Post-Crash

\begin{tabular}{|l|c|c|}
\hline $\begin{array}{l}\text { December 1997 RIC List: } \\
\text { All “A” Rated Commercial } \\
\text { Banks (22 in Total) }\end{array}$ & $\begin{array}{l}\text { December 1998 RIC List: } \\
\text { Previously “A” Rated Banks } \\
\text { Still on List }\end{array}$ & $\begin{array}{l}\text { December 1998 RIC List: } \\
\text { Previously “A” Rated Banks } \\
\text { Removed from List }\end{array}$ \\
\hline $\begin{array}{l}\text { (6) Deposit Banks } \\
\text { (From Table 3) }\end{array}$ & 0 & 6 \\
\hline (16) Other Commercial Banks & 9 & 7 \\
\hline
\end{tabular}

Source: Rating Information Center, www.rating.ru

Given the general opacity of the Russian financial sector, we cannot know the precise intentions and motives of specific banks. We can, however, offer informed hypotheses as to why deposit banks were disproportionately affected by the August crash. One explanation is that attracting deposits required absorbing costs and assuming risks that turned out to be greater than initially anticipated. Winning depositors' trust required 
large up-front investments in the form of heavy advertising expenditures (Avdasheva and Yakovlev, 2000). However, given the experiences from earlier in the decade, the ability of any given amount of advertising to increase deposits had likely been diminished. The negative correlation between advertising and institutional longevity in 1994-95 undermined advertising's value as a signal of longevity. In short, as depositors became increasingly skeptical of advertising, the advertising costs that needed to be incurred to attract a fixed amount of deposits rose.

The rising cost of attracting new customers into an increasingly discredited market may have pushed the banks intent on building their deposit base into assuming increasingly high levels of risk on the asset side of their balance sheets. The only way for many of these banks to generate the resources needed to attract new customers, given their waning trust, was to adopt high-risk investment strategies. Low-risk, low-return strategies would not generate the income needed to reverse the cycle of distrust. Indeed, relative to their liabilities, Russia's leading deposit banks became disproportionately exposed to ruble-denominated assets, particularly Russian government securities. Russian debt carried a significant risk premium in light of the government's ongoing budgetary problems, but so long as the ruble remained strong and the government made good on its obligations, the deposit banks and their clients would remain solvent. But when the government devalued its currency and defaulted on its bonds in August 1998, banks wedded to this strategy were hit extremely hard. An independent audit of the pre-crash leaders in the deposit market revealed the following post-crash capital-to-assets ratios: Inkombank, -4.5; SBS-Agro, -2; Rossiisskii Kredit -1.5; and Menatap, -1.0 (Russian 
Economic Trends, 1999, Issue 1). In the immediate aftermath of the crash, these banks simply did not have the resources to meet their obligations to depositors. ${ }^{13}$

The impact of their risky investment strategies on household depositors was compounded by banks' grossly opportunistic behavior in the aftermath of the August crash. Recognizing the damage done to their reputation, banks were more apt to view their ongoing interactions with depositors as an endgame. With the prospects of rebuilding or even maintaining their deposit base in doubt, a "take the money and run" strategy became increasingly attractive. In mature market economies, failed banks enter a liquidation process in which external regulators shield a bank's good assets from departing managers. In Russia, however, the Central Bank's supervision of insolvent banks was both slow and opaque (Moscow Times, August 17, 1999: VIII). Many of the "failed" deposit banks, now less concerned about their reputations, exploited the weak regulatory environment, quickly transferring their remaining good assets into new legal entities (so-called "bridge" or "shadow" banks) with essentially the same set of owners.

New "bridge" banks held none of the liabilities of their "daughter" banks, leaving obligations to depositors in the hands of banks that just had many of their bestperforming assets stripped from their control. For instance, soon after the August crash, Alexander Smolensky, the founder and head of SBS-Agro, helped establish the First Mutual Credit Society, a bank that absorbed many of the assets of his old institution but none of its liabilities. Smolensky claimed that the "rebirth" of his bank was completely legal even though many of SBS-Agro's depositors received only a small fraction of what was owed them (Moscow Times, October 10, 2000). Despite receiving more than $\$ 200$ million in stabilization credits from the CBR, SBS-Agro claimed to be unable to meet its 
obligations, offering many of its depositors settlement packages composed of office furniture and package tours. (Moscow Times, August 17, 1999). Smolensky even mocked his former clients for their naivete, saying that his "hair stood on end" when he saw that some Russians had deposited more than $\$ 1$ million in his bank; they "must be idiots," he observed (Moscow Times, October 10, 2000: 6). ${ }^{14}$

Nearly every major deposit bank created a "bridge" bank. Rossiisskii Kredit created Impeksbank to continue its operations. Menatep St. Petersburg took over Menatep's forty-six Moscow branches and acquired several of its sister bank's regional offices as well. Promstroibank St. Petersburg similarly took over the operations of Promstroibank Russia. Inkombank was the only major deposit bank that went bankrupt without transferring a large portion of its best-performing assets to a new organization with many of the same owners. ${ }^{15}$

In practice, the exact combination of factors that gave rise to a particular bank's unwillingness or inability to honor its deposit obligations is difficult to discern. Whether the mix of reasons was weighted more toward the macro-level shock, risky investment strategies, or asset stripping, the August events and their aftermath only validated depositors' feelings of distrust toward commercial banks. Household ruble deposits in commercial banks dropped by sixteen billion (47.6 percent) in the last half of 1998, while household deposits in foreign exchange decreased even more dramatically by $\$ 2.3$ billion (58 percent) (CBR 1998 Annual Report).

The money that did remain in the commercial banking sector migrated toward banks in which state bodies still played a significant role. As shown in Table 5, the state held significant ownership rights in four of the ten leading deposit banks in January 
1999. ${ }^{16}$ These four experienced the largest absolute increases in deposits during the first half of 1999. Although only Sberbank offers deposits that are explicitly insured, the participation of state entities seemed to be increasingly interpreted by depositors as an implicit signal of an institution's stability.

Table 5: Top Operating Banks in the Household Deposit Market, Post-Crash

\begin{tabular}{|l|c|c|}
\hline $\begin{array}{l}\text { Top Operating Banks in } \\
\text { Deposit Market }\end{array}$ & $\begin{array}{l}\text { Change in Ruble Deposits } \\
\text { from January } 1^{\text {st }}-\text { July } 1^{\text {st }} \\
\text { 1999 (1,000s of Rubles) }\end{array}$ & $\begin{array}{l}\text { Bank's Rating (and } \\
\text { changes) } \\
\text { to 5/1/99 }\end{array}$ \\
\hline Sberbank & $37,369,912$ & A2 \\
\hline Gazprombank & 638,883 & A1 \\
\hline International Moscow Bank & 2,113 & A1 \\
\hline Alfa & 512,052 & B3 to B2- \\
\hline Vneshtorgbank & $1,668,557$ & B2- to B2 \\
\hline Vozroshdeniya & $-209,915$ & B3 \\
\hline Bank of Moscow & 854,536 & B3 to B2 \\
\hline Avtobank & $-205,468$ & B3 to B3- \\
\hline Evrofinance & 282,201 & B1 to B1- \\
\hline Petrokommerts & 123,748 & B3- to B2 \\
\hline Moscow Industrial Bank & $-61,733$ & \\
\hline
\end{tabular}

Source: Rating Information Center, www.rating.ru

Italics designate banks with strong government ownership. The correlation here between state participation and deposit mobilization stands in stark contrast to the absence of any clear relationship between deposit mobilization and the reliability grades of RIC. Presumably there are many factors that influence the choice of a household to deposit its savings with a given bank. The probability that the bank will be able to honor its obligation to depositors when they wish to withdraw funds is only one factor, albeit an influential one. The geographical proximity of a branch, the quality and range of services offered, as well, of course, as the rate of interest paid on deposits all play a role. We, 
therefore, should not expect to see all deposits being placed in the bank widely recognized to be the safest haven for deposits. Nor might we even expect to observe a particularly strong positive correlation between a bank's reliability ranking and the percentage of aggregate deposits attracted. We can, however, get at the answer of a rating's impact by examining whether or not a bank's ability to attract funds changes when its rating changes. Assuming that the other factors affecting deposits remain fixed, a bank could be expected to have more luck attracting funds when the measurement of its reliability improves. And conversely, a withdrawal of deposits after a down-grading in its reliability would not be a surprise. We might further hypothesize that such effects would be exaggerated during a period in which the stability of the banking system as a whole is in question. But, surprisingly, Table 4 shows that the change in deposits at these banks does not correlate at all with the reassessment of their reliability by the rating agency.

The seeming ineffectiveness of RIC represents one more piece of evidence of the failure to produce trust in the Russian retail banking market. As Table 3 pointed out, virtually all of the top deposit-banks had received an "A" rating before the crash. Yet, most of these banks proved to be either unable or unwilling to fulfill their obligations to depositors in the latter half of 1998. Coarse group-level differentiating mechanisms whether a bank was government-owned or privately-owned - proved more useful to depositors than more refined rating information on individual banks.

\section{Discussion}

When Russian financial markets were liberalized in 1992, hundreds of new private financial institutions offered up their services to households that possessed both 
the means and the desire to save. Both a well-defined supply of and demand for savings deposits clearly existed. However, a well-functioning market that linked the two was not yet in place, and the degree to which Russian households would entrust their savings to the new commercial banks was uncertain. Despite the potential gains to trade in the Russian deposit market, the inability to create trust in the contractual promises of commercial banks led to the collapse of the entire market.

The macro-economic consequences of these developments should not be underestimated. Government estimates place the amount of cash that Russians have stashed at home, outside the formal financial system, in the tens of billions of dollars. Despite the re-structuring demands of former state-owned enterprises and the capital needs of startups, Russia's banks have done little lending to the private sector (EBRD, 1998).

Although this is in part due to difficulties in assessing creditworthiness and enforcing loan contracts, the inability of Russia's banks to mobilize deposits has played a large role as well.

What explains Russian banks' inability to reverse the cycle of distrust? Diego Gambetta's (1988: 234) explanation of the self-reinforcing nature of distrust parallels our own:

Deep distrust is very difficult to invalidate through experience, for either it prevents people from engaging in the appropriate kind of social experiment or, worse, it leads to behavior which bolsters the validity of distrust itself ... Once distrust has set in it soon becomes impossible to know if it was ever in fact justified, for it has the capacity to be self-fulfilling, to generate a reality consistent with itself. It then becomes individually "rational" to behave accordingly, even for those previously prepared to act on more optimistic expectations. 
Gambetta, like Zucker (1986), emphasizes the role of beliefs in defining "rationality" in local settings. In the Russian case, depository contracts became interpreted based on previous experience with similar contracts. In turn, a growing distrust of all contractual obligations led individuals to refrain from "engaging in the appropriate kind of social experiment" that might lead to a reconsideration of initial beliefs. The population avoided transactions with commercial banks, the very type of "social experiment" that had the potential to allow banks to establish a reputation for reliability. In fact as the market for privately-provided deposits sputtered, the incentive structure for commercial banks changed. Short-term opportunism, a "take the money and run" strategy, became increasingly attractive. Distrust bred self-confirming actions.

Certainly, the Russian case reinforces the need for governmental supervision in nascent financial markets (Stiglitz, 1993). In order to avoid a cycle of distrust, Russia would have needed state regulatory bodies that were both willing and able to curb the opportunistic behaviors of early market entrants. Just as importantly, the Russian case highlights that the creation of institutional trust fundamentally rests on the beliefs and attitudes of those who most rely on institutions in everyday practice. Breaking the cycle of distrust will require not only regaining the confidence of depositors in financial organizations, but also developing confidence that state structures can credibly control the boundaries of legitimate competitive behavior. The history of the Russian market has demonstrated again and again that both private and public organizations have had little success in defining the rules and norms of Russia's new markets.

Putnam's analysis of variation in the economic performance of Italian regions provides a comparative case for the Russian experience. He (1993:177) suggests that the 
economic and political performance of an Italian region depends on whether it has created a high-trust or a low-trust social equilibrium:

Stocks of social capital, such as trust, norms and networks, tend to be selfreinforcing and cumulative. Virtuous circles result in social equilibrium with high-levels of cooperation, trust, reciprocity, civic engagement and collective well-being. These traits define the civic community. Conversely, the absence of these traits in the uncivic community is also self-reinforcing. Defection, distrust, shirking, exploitation, isolation, disorder and stagnation intensify one another in a suffocating miasma of vicious circles.

As applied to the study of arms-length exchange, the self-reinforcing nature of trust suggests two different equilibria. Successful markets have established a virtuous cycle of trust-production that provides both short and long-term benefits to high-levels of cooperation and trust. Yet, the Russian case suggests that the formation of the virtuous circle of initial market creation is in itself a significant challenge. A vicious cycle of distrust may just as easily lead to a low-equilibrium trap that brings growing benefits to defection and distrust.

Guiso, Sapienzo and Zingales (2001) similarly demonstrate the importance of collective trust in influencing market development in Italy. Using similar measures as Putnam to measure differences in social capital across Italian regions, they find that in regions with higher levels of social capital, households invest more in stock, use checks more frequently and have greater access to institutionalized sources of credit. That is, trust correlates with a more important role for impersonal financial transactions. Similar findings are now becoming apparent in Russia. Commercial banks rely on personal ties and networks to develop and retain customers, as they have been unable to develop the impersonal markets in deposits, commercial lending or credit card activity that provide 
the foundation of banking activity in established western markets (Dinello, 1999; Gueseva and Rona-Tas, 2001).

Our study, however, differs from the low-trust equilibrium traps identified in the research on Italy. The choice of financial instruments in Guiso's et al. (2001) study depends on a measure of regional social capital that remains relatively stable across long periods of time. The degree of social capital in a region is taken to be exogenous to the everyday activities of financial markets. Our examination of the formation of the Russian market, however, emphasizes the endogenous formation of institutional beliefs in initial periods of market creation. Cultural arguments that Russians were somehow disinclined to participate in financial markets seems to be at odds with actual events. In fact, Russians were especially eager to enter the new markets in the early 1990s. Collective beliefs emerged from the negative experiences that these neophyte investors suffered at the hands of unscrupulous financial operators. Russian depositors did not act on culturally determined stereotypes of private banks; instead they created new stereotypes based on their lived experience with these new private actors.

Raiser et al. (2001) provides strong supportive evidence, recently collected through the World Values Survey, to suggest that Russians' distrust of private organizations is endogenous to the post-communist transition. Respondents were asked to rate their degree of confidence in over a dozen public and private sector institutions: the press, the legal system, the civil service, the enterprise sector, etc. As recently as 1990, Russians' measure of confidence in private companies, 2.37, was higher than the average for countries in Eastern Europe and the former Soviet Union, 2.18. In 1995, however, Russians' lack of confidence in companies stood out as the lowest of the twenty 
transition countries surveyed. Of course, during this five-year period, Russia went through a whole series of changes that would re-shape social institutions and attitudes. But to a large extent these changes were mirrored elsewhere in the former socialist bloc. As we can see in Table 6, popular confidence in the legal system, the civil service and the press changed in Russia much as it did in other transition economies.

Table 6: Change in the Level of Confidence in Formal Institutions Between 19901995, World Value Surveys

\begin{tabular}{|l|c|c|c|c|}
\hline & Legal System & Civil Service & Press & Companies \\
\hline Transition Countries & -.03 & -.03 & -.13 & +.11 \\
\hline OECD Countries & +.10 & .00 & -.06 & +.02 \\
\hline Russia & -.03 & .02 & -.11 & $\mathbf{- . 5 2}$ \\
\hline
\end{tabular}

Note: The numbers in the table represent the difference between the scores for 1995 and 1990 from the World Values Surveys on confidence in formal institutions. A positive number represents an increase in the level of expressed confidence toward an institutional form during this time period.

Source: Raiser et. al. (2001).

But unlike other countries in the region that, on average, experienced a growing level of popular confidence in companies, Russian companies experienced a dramatic erosion of trust from 1990 to 1995. Most likely, the experience of Russian households with the nascent, unregulated financial sector had a large impact on these numbers. Interestingly, Albania, another country that had a particularly bad experience with the bankrupting of poorly controlled pyramid schemes, scored the second lowest in terms of the trust of companies in 1995. Although it is difficult to establish a direct causal link here, the loss of trust in private financial organizations most likely gave rise to an 
environment in which the level of skepticism toward all private enterprises (even rating agencies) rose.

An important question for future market development in Russia is whether the dynamic of a vicious circle of decline can be reversed. Increased regulation of the market clearly needs to be part of the solution. However, in order to be effective, new laws and regulations will themselves need to be trusted before the Russian population dares to rely upon collective institutions to protect market transactions. Building trust in public institutions has become a critical component of market building in post-communist Russia. 


\section{References}

Abarbanell, Jeffrey S. and Anna Meyendorff. (1997). Bank Privatization in PostCommunist Russia: Case of Zhilsotsbank. Journal of Comparative Economic, 25 (1), 62-96.

Avdasheva, Svetlana and Andrei Yakovlev. (2000). Asymmetric Information and the Russian Individual Savings Market. Post-Communist Economics, 12 (2), 165 185.

Bazhenova Ol'ga, Yaroslav Skvortsov, Yurii Katsman. (1995). Nastupil god aktivnoi bor'by za den'gi naseleniia. Kommersant-Daily, No. 42, March 9 ${ }^{\text {th }}, 1995$.

Boycko, Maxim, Andrei Shleifer, and Robert Vishny. 1995. Privatizing Russia. Cambridge, Mass.: MIT Press.

Bulletin of Banking Statistics. Central Bank of the Russian Federation. Moscow: Russia.

Coleman, James. 1990. Foundations of Social Theory. Cambrdge, Mass.: Harvard University Press.

Delacroix, Jacques, and Hayagreeva Rao. (1994). Externalities and Ecological Theory: Unbundling Density Dependence. In Joel Baum and Jitendra Singh (eds.), Evolutionary Dynamics of Organizations, New York: Oxford University Press.

Dinello, Natalia. (1999). The Russian F-Connection: Finance, Firms, Friends, Families and Favorites. Problems of Post-Communism, 46 (1), 24-33.

European Bank for Reconstruction and Development (EBRD). (1998). Transition Report 1998: Financial Sector in Transition. London: EBRD, 1998.

Federal Commission for the Securities Market. (1996). Training Manual for Perspective Unit Fund Managers. Manuscript (In Russian).

Gambetta, Diego. (1988). Can We Trust Trust?. In Diego Gambetta (ed.), Trust: Making and Breaking Cooperative Relations, New York: Basil Blackwood Ltd.

Garvy, George. (1977). Money, Financial Flows, and Credit in the Soviet Union. Cambridge, MA: Balinger Publishing.

Gerschenkron, Alexander. 1962. Economic Backwardness in Historical Perspective: A Book of Essays. Cambridge, Mass.: Belknap Press. 
Gueseva, Alya and Akos Rona-Tas.( 2001). Uncertainty, Risk and Trust: Russian and American Credit Card Markets Compared. American Sociological Review, 66 (5), 623-647.

Guiso, Luigi, Paola Sapienza and Luigi Zingales. (2001). The Role of Social Capital in Financial Development. Working Paper No. 511, The Center for Research in Security Prices.

Hoffman, David. (2002). The Oligarchs. New York: Public Affairs.

Johnson, Juliet. (2000). A Fistful of Rubles: The Rise and Fall of the Russian Banking System. Ithaca: Cornell University Press.

Klein, Daniel. (2000). Reputation: Studies in the Voluntary Elicitation of Good Conduct. Ann Arbor: The University of Michigan Press.

Monitoring of Public Opinion. Russian Centre for Public Opinion Research (VTsIOM). Moscow: Russia.

Nelson, Phillip. (1974). "Advertising as Information." Journal of Political Economy, 84, 729-754.

Putnam, Robert. (1993). Making Democracy Work: Civic Traditions in Modern Italy. Princeton, NJ: Princeton University Press.

Raiser, Martin, Christain Haerpfer, Thomas Nowotny and Claire Wallace. (2001). "Social Capital in Transition: A First Look at the Evidence," Working Paper No. 61, European Bank for Reconstruction and Development (EBRD).

"Russian Economic Trends." Russian European Centre for Economic Policy. Moscow: Russia.

Sachs, J. 1993. Poland's jump to the market economy. Cambridge, MA: MIT Press.

Shapiro, Susan. (1987). "The Social Control of Impersonal Trust," American Journal of Sociology 93 (3), 623-58.

Stiglitz, Joseph. (1993). The Role of the State in Financial Markets. Proceedings of the World Bank Annual Conference on Development Economics. Washington, D.C..

Warner, Andrew. (1998). The Emerging Russian Banking System. Economics of Transition, 6 (2), 333-47. 


\section{ENDNOTES}

${ }^{1}$ The idea of "reputational externality" is based on Delacroix and Rao (1994).

${ }^{2}$ The data in Figure 1 were calculated by dividing the change in the stock of savings over a period of time (the net flow of savings) by after tax household income over the same period of time.

${ }^{3}$ For information about MMM, see Izvestiya, December 11, 1994, December 18, 1994, January 19, 1995; Nezavisimaya Gazeta, July 28, 1994 pp. 1-2; Chicago Tribune, August 16, 1994. For information about Tibet, see Kommersant-Daily, No.49, March 18, 1995 or Kommersant, No. 11, March 29, 1994, p.48.

${ }^{4}$ There were no recorded bank failures in 1992, 19 in 1993 and 24 in the first half of 1994.

${ }^{5}$ Responses of "hard to answer" were not included in the summary data presented in Table 2.

${ }^{6}$ Somewhat inexplicably, these monies had previously been mixed in with the foreign currency settlement accounts of firms. We thank Mikhail Matovnikov for clarifying this point.

${ }^{7}$ We show later in the paper that even the $1 \%$ investment figure in "private" banks is misleading. Many of the banks that attract new deposits outside of Sberbank are themselves government-owned or controlled. For instance, the Bank of Moscow, which enters the deposit market during this time period, is controlled by the city of Moscow.

8 "Experience goods" are products whose characteristics are not discernable immediately through inspection to potential customers. Rather, they are revealed over time through exposure and/or use. The veracity of a financial institution's promise to honor its liabilities possesses this characteristic.

${ }^{9}$ Avdasheva and Yakovlev (2000) only examine financial institutions that had formal licenses to operate as banks. If unlicensed financial companies like MMM were included in the analysis, then the proposition that advertising expenditures were a sterile signal of future behavior is even stronger. MMM incurred huge advertising expenditures to attract new investment into its pyramid scheme.

${ }^{10}$ In the mid-1990s, the CBR published RIC's data in its own in-house statistical abstracts. RIC's rankings also appeared in prominent news and business periodicals with great frequency and regularity. In compiling its ratings, RIC relies in part on financial data assembled and released by the banks themselves. But given the relative ease of manipulating financial information in Russia, RIC emphasizes that it supplements these 
data with on-site interviews and frequent consultation with their own network of industry experts and insiders.

${ }^{11}$ The other banks on the list were Alfabank, Avtobank, Conversbank, Imperial, International Company for Finances and Investment, International Industrial Bank, International Moscow Bank, Mezhcombank, Mosbiznesbank, Moscow Industrial Bank, Orgbank, Rosnevshtorgbank, Tokobank, Toribank, Uneximbank, Vozroshdeniya. As we have already included SBS-Agro, we do not include Agromprombank seperately.

${ }^{12}$ The difference in the rating changes between the two groups ("A" rated deposit banks vs. "A" rated nondeposit banks) is statistically significant (chi-square $=5.712, \mathrm{p}=0.017$ ).

${ }^{13}$ Foreign investors seemed to make the same mistakes as domestic investors in trusting their money with the banks that were most likely to disappear following the August 1998 crash. The top three foreign debtors before the crash were SBS-Agro ( $\$ 1.196$ billion in foreign debt), Inkombank ( $\$ 820$ million) and Rossiikskii Kredit (\$648 million) (Kommersant, 1998, reported in Johnson, 2000: 210). Moreover, Russian banks defaulted on billions of dollars in forward currency contracts signed with foreign investors. Inkombank, for instance, reneged on an estimated $\$ 1.88$ billion in currency contracts following the devaluation of the ruble in 1998 (Johnson, 2000: 212).

${ }^{14}$ Smolensky was no less kind to his foreign creditors. When asked about the foreigners who lost more than $\$ 1$ billion in SBS-Agro, he replied that they deserved only "dead donkey ears" (Wall Street Journal, October 2000, cited in Hoffman, 2002: 440.).

${ }^{15}$ Inkombank's bankruptcy was also tarnished with scandal. The US government alleged that Inkombank had been a central player in moving billions of dollars out of Russia secretly through Bank of New York accounts. See Johnson (2000:132) and USA Today, September 24, 1999 for a description of the accusations of illegal activity made against Inkombank.

${ }^{16}$ For instance, Gazprom, a natural gas monopoly with a high-degree of state ownership, controls Gazprombank; and the city of Moscow controls the Bank of Moscow. 


\section{DAVIDSON INSTITUTE WORKING PAPER SERIES - Most Recent Papers}

The entire Working Paper Series may be downloaded free of charge at: www.wdi.bus.umich.edu

CURRENT AS OF 6/30/03

\begin{tabular}{|c|c|c|}
\hline Publication & Authors & Date \\
\hline $\begin{array}{l}\text { No. 588: Institutions and the Vicious Circle of Distrust in the Russian } \\
\text { Household Deposit Market, 1992-1999 }\end{array}$ & Andrew Spicer and William Pyle & June 2003 \\
\hline $\begin{array}{l}\text { No. 587: Foreign Direct Investment and the Business Environment in } \\
\text { Developing Countries: the Impact of Bilateral Investment Treaties }\end{array}$ & $\begin{array}{l}\text { Jennifer Tobin and Susan Rose- } \\
\text { Ackerman }\end{array}$ & June 2003 \\
\hline No. 586: Trust in China: A Cross-Regional Analysis & Rongzhu Ke and Weiying Zhang & June 2003 \\
\hline No. 585: Family Control and the Rent-Seeking Society & $\begin{array}{l}\text { Randall Morck and Bernard } \\
\text { Yeung }\end{array}$ & June 2003 \\
\hline $\begin{array}{l}\text { No. 584: Wage Determination: Privatised, New Private and State } \\
\text { Owned Companies, Empirical Evidence from Panel Data }\end{array}$ & $\begin{array}{l}\text { Tomasz Mickiewicz and Kate } \\
\text { Bishop }\end{array}$ & June 2003 \\
\hline No. 583: An Investigation of Firm-Level R\&D Capabilities in East Asia & $\begin{array}{l}\text { Gary H. Jefferson and Zhong } \\
\text { Kaifeng }\end{array}$ & June 2003 \\
\hline $\begin{array}{l}\text { No. 582: R\&D and Technology Transfer: Firm Level Evidence From } \\
\text { Chinese Industry }\end{array}$ & $\begin{array}{l}\text { Albert G.Z. Hu, Gary H. } \\
\text { Jefferson, Guan Xiaojing and } \\
\text { Qian Jinchang }\end{array}$ & June 2003 \\
\hline $\begin{array}{l}\text { No. 581: Credit Market Disequilibrium in Poland: Can We Find } \\
\text { What We Expect? Non-Stationarity and the "Min" } \\
\text { Condition }\end{array}$ & $\begin{array}{l}\text { Christophe Hurlin†and Rafal } \\
\text { Kierzenkowski }\end{array}$ & June 2003 \\
\hline $\begin{array}{l}\text { No. 580: Does it Take a Lula to go to Davos? } \\
\text { A Brief Overview of Brazilian Reforms, 1980-2000 }\end{array}$ & $\begin{array}{l}\text { Nauro F. Campos, Armando } \\
\text { Castellar Pinheiro, Fabio } \\
\text { Giambiagi and Maurício M. } \\
\text { Moreira }\end{array}$ & June 2003 \\
\hline $\begin{array}{l}\text { No. 579: Ceaseless Toil? Health and Labor Supply of the Elderly in } \\
\text { Rural China }\end{array}$ & $\begin{array}{l}\text { Dwayne Benjamin, Loren Brandt } \\
\text { and Jia-Zhueng Fan }\end{array}$ & June 2003 \\
\hline $\begin{array}{l}\text { No. 578: Shadow Economy, Rent-Seeking Activities and the Perils of } \\
\text { Reinforcement of the Rule of Law }\end{array}$ & Ekaterina Vostroknutova & June 2003 \\
\hline $\begin{array}{l}\text { No. 577: No Pain, No Gain: Market Reform, Unemployment, and } \\
\text { Politics in Bulgaria }\end{array}$ & Neven Valev & June 2003 \\
\hline $\begin{array}{l}\text { No. 576: Power Analysis of the Nice Treaty On the Future of European } \\
\text { Integration }\end{array}$ & Yener Kandogan & June 2003 \\
\hline $\begin{array}{l}\text { No. 575: Democracy's Spread: Elections and Sovereign Debt in } \\
\text { Developing Countries }\end{array}$ & $\begin{array}{l}\text { Steven A. Block, Burkhard N. } \\
\text { Schrage, and Paul M. Vaaler }\end{array}$ & June 2003 \\
\hline $\begin{array}{l}\text { No. 574: Reintroducing Intergenerational Equilibrium: Key Concepts } \\
\text { Behind the New Polish Pension System }\end{array}$ & Marek Góra & June 2003 \\
\hline $\begin{array}{l}\text { No. 573: Why Does FDI Go Where It Goes? New Evidence From the } \\
\text { Transition Economies }\end{array}$ & $\begin{array}{l}\text { Yuko Kinoshita and Nauro F. } \\
\text { Campos }\end{array}$ & June 2003 \\
\hline $\begin{array}{l}\text { No. 572: Private Savings in Transition Economies: Are There Terms of } \\
\text { Trade Shocks? }\end{array}$ & Abdur R. Chowdhury & May 2003 \\
\hline $\begin{array}{l}\text { No. 571: On the long-run determinants of real exchange rates for } \\
\text { developing countries: Evidence from Africa, Latin America and Asia }\end{array}$ & Imed Drine and Christophe Rault & May 2003 \\
\hline $\begin{array}{l}\text { No. 570: A re-examination of the Purchasing Power Parity using non- } \\
\text { stationary dynamic panel methods: a comparative approach for } \\
\text { developing and developed countries }\end{array}$ & Imed Drine and Christophe Rault & May 2003 \\
\hline $\begin{array}{l}\text { No. 569: How Important is Ownership in a Market with Level Playing } \\
\text { Field? The Indian Banking Sector Revisited }\end{array}$ & $\begin{array}{l}\text { Sumon Kumar Bhaumik and } \\
\text { Ralitza Dimova }\end{array}$ & May 2003 \\
\hline $\begin{array}{l}\text { No. 568: On Types of Trade, Adjustment of Labor and Welfare Gains } \\
\text { During Asymmetric Liberalizations }\end{array}$ & Yener Kandogan & May 2003 \\
\hline $\begin{array}{l}\text { No. 567: Technological Progress Through Trade Liberalization in } \\
\text { Transition Countries }\end{array}$ & Yener Kandogan & May 2003 \\
\hline $\begin{array}{l}\text { No. 566: Intra-industry Trade of Transition Countries: Trends and } \\
\text { Determinants }\end{array}$ & Yener Kandogan & May 2003 \\
\hline $\begin{array}{l}\text { No. 565: Local Protectionism and Regional Specialization: Evidence } \\
\text { from China's Industries }\end{array}$ & $\begin{array}{l}\text { Chong-En Bai, Yingjuan Du, } \\
\text { Zhigang Tao, Sarah Y. Tong }\end{array}$ & May 2003 \\
\hline
\end{tabular}

